outlines-2000.qxd 23-11-00 12:55 Side 61

\title{
Practice Research and Learning Resources ${ }^{1}$ A joint venture with the initiative 'Wild Learning'
}

\begin{abstract}
Summary
In this article I describe Practice Research (PR) as a collective, contextualized project. First I will introduce 'PR as practice' by presenting the construction of 'Learning Resources in the community of Wild Learning' constructed among others by 'Wild Learning' and my self. Then I will discuss 'Practice research in theory and methodology' comprising three main features: First the relation between theory and practice is characterized as a joint venture. Second I stress that doing PR means not only having a joint venture with the professionals in a specific practice - it also means to analyze the specific practice from 'the outside', e.g. by relating it to how it is part of different participants' everyday life. I call this feature decentered analysis. The third important feature of PR is critical analysis; analyzing practice as both action contexts and discourse. Finally I present some critical reflections on the ideals, problems and dilemmas when working with PR.
\end{abstract}

1 Thanks to Morten Nissen, Lotte Huniche and Klaus Nielsen, to Søren Magnussen, to the 'practice research group' at Copenhagen University (Peter Elsass, Jean Lave, Ole Dreier and David Metz), and to the Outlines editor (Hysse Forchammer) and the reviewer for very productive comments and discussions of earlier versions of this paper. And also thanks to Anne Slej Kristensen and Yvonne McAneny for helping to improve the English.

\section{Introduction}

$\mathrm{I}$ n Denmark and Germany a number of researchers, including myself, are engaged in developing critical psychology and doing action research within the social and psychological field. This kind of action research we call practice research $(\mathrm{PR})$. In Berlin the tendency has been for researchers to primarily do practice research with professionals, analyzing and trying to expand working conditions in order to become better able to practice Critical Psychology (Holzkamp \& Markard 1989, Fahl \& Markard 1999, Dreier 1994, Osterkamp 1992, also see Nissens historical analysis of this tradition, Nissen 2000a). In Copenhagen (Denmark) there has been increasing tendency to involve the users and to do decentered analysis (Dreier 1996, 1997, Huniche 1997, Нøjholt 1993, 1999, Kousholt \& Bostrup 1998, Mørck 1995, 1996, 1998, Nissen 2000b, Rasmussen 1994, Østergaard 1999 just to mention some of the projects). It is primarily this 'Copenhagen branch' of practice research that I will be presenting and discussing here. 
62

In this paper I will argue that practice research can be understood as a socially situated research within concrete 'joint ventures', which establish 'decentered first person standpoints' in practice - often from the users' perspective. At the same time PR seeks to make critique in solidarity with practice, being critical of dominating ideologies and discourses that we (the joint venture) are both part of but also try to work against and change. I want to show how the concrete joint ventures of practice research mainly originate from the theoretical core concepts developed within critical psychology (such as 'participation', 'action context', 'first person standpoint' etc.) and from concrete practice: The action contexts and communities involved - rather than from abstract method, you as researcher can apply wherever. This also means that concrete practice research projects come in many versions according to the co-operating communities and the participants being part.

To give an impression of practice research as practice - in many ways open-ended, 'on the move', with no clear beginnings and endings - I will discuss these issues through a presentation of a joint venture between myself, Morten Nissen ${ }^{2}$ and the initiative Wild Learning (WL). The joint venture is mainly reflected in the summer of 1999 where WL and my own Ph.D. project were both still in their very early phases. But even though I at that time only had been working on my Ph.D. scholarship for about a year (being on maternity leave most of that time) and Wild Learning only had their name and finances for about half a year, I still think these reflections on 'PR in action' have their place. Both parties in this joint venture were not newcomers just meeting each other and trying to establish a joint venture. This prac-

2 Ph.D. Morten Nissen from Copenhagen University and I are doing this practice research project together. tice research project has roots anchored throughout the last decade back into other practice research projects between people connected in different ways to the local cultural community of WL and colleagues from my own research community back then, mainly connected to critical psychology at Copenhagen University. In this group of practice researchers, we are often several researchers researching within the same field. Often we use colleagues' contacts and networks and we discuss our research. As part of this group I have followed many discussions on this local field for quite some time and I have participated in several other practice research projects related to marginality and youth.

Throughout this paper I will present boxes with information on WL, my research process, selected participants and examples of their activities etc. All these boxes are made in the summer of year 2000 to give you a better idea of what WL (as well as my ph.D. project) has developed to be over its first 1/2-2 years of existence.

This paper focuses primarily on practice research and the joint venture with WL. But practice research projects are always about something and this research is about 'learning from the margin' (which is my present working title of the Ph.D. project). Therefore I will also to some extend introduce the learning issue; analyzing 'learning resources' within the 'learning environment' of 'Wild Learning', and examples of 'trajectories' exceeding marginality. These discussions will primarily be used to concretize the discussions of practice research and critical psychology and in that way only be a secondary theme. I won't be going into thorough discussions of the theoretical concepts of learning and marginality.

Lets start with describing this specific social work development initiative that calls itself 'Wild Learning'. 


\section{Description of 'Wild}

\section{Learning, ${ }^{3}$}

W

ild Learning organizes learning in social work among young people and social workers. It is the most recent 'branch' of a Copenhagen social work project called 'The Wild Young'. As can be seen in figure 1 this 'branching' or 'budding' ${ }^{4}$ of projects is a common way these alternative projects develop and change over time. The projects and their network (the dotted lines) shown in figure 1 are not in any way a complete picture of the WL community including all the projects they cooperate with. I am mainly showing the projects Morten Nissen and I have been directly in contact with or co-operating with.

One of WL's main goals is to mobilize the resources of "wild' 5 youngsters in the sense that they are or have been socially excluded, criminals, drug users or kids who spend most of their time on the streets. These 'wild' youngsters including those who become social workers are on the other hand also full of energy and take pride in what they are doing in different projects connected to their local community. They manage to be part of projects; both using and organizing different activities for young people, and at the same time they are often fighting for better conditions for 'wild' youngsters in general.

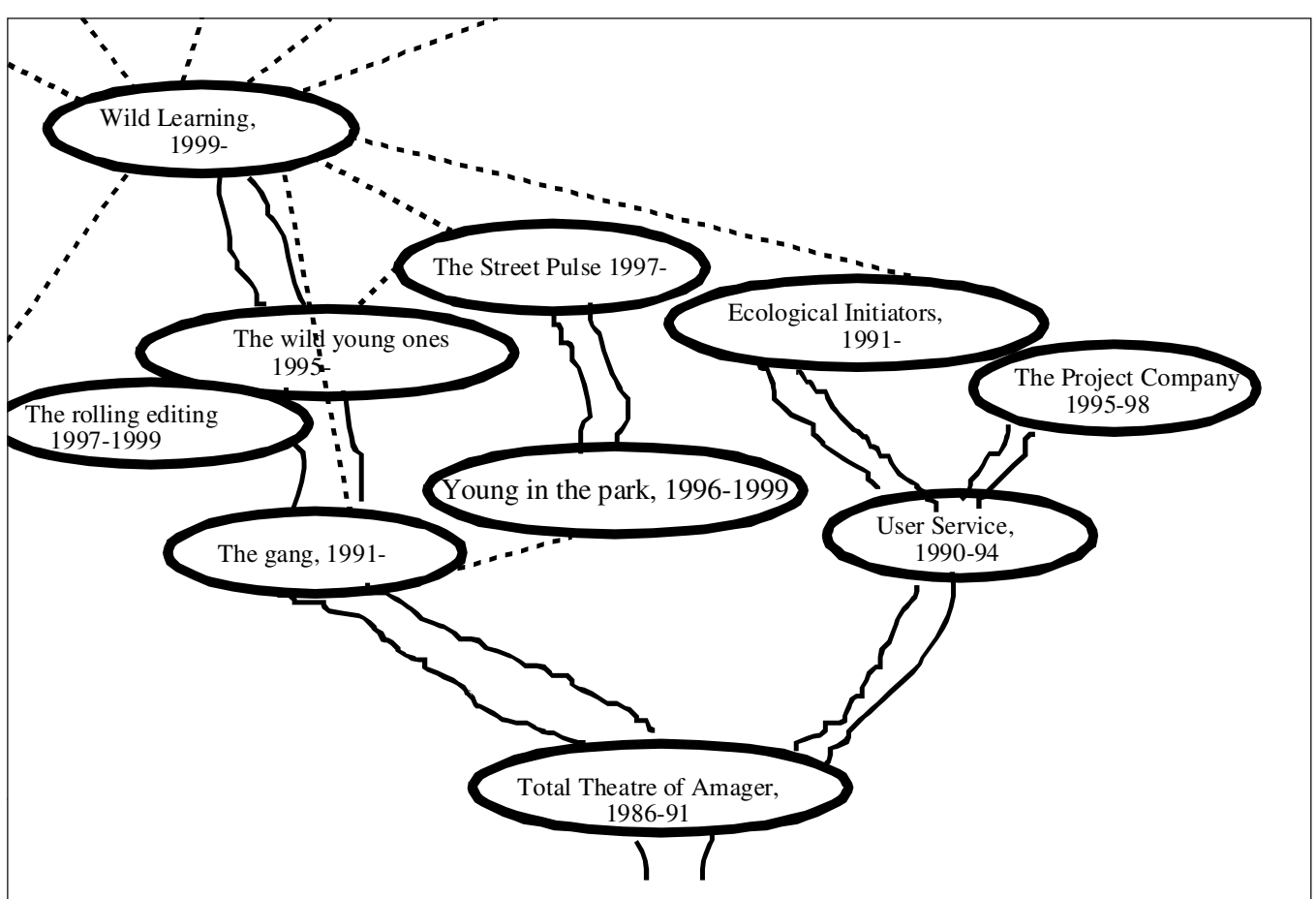

Figure 1: Some projects which are part of the network and community of WL

3 Also see Nissen 1999 and 2000b, which covers more complex analyses of the WL community and its predecessors as 'local cultural organizations'.

4 'This budding process will be explained later.
5 In this paper I am using WL's own term 'wild' for people with so-called 'marginalized backgrounds'. I am using the term 'wild' also to get the positive dimension of the term and in that way I am trying not to marginalize people further by mainly calling them 'marginalized'. 
64

Wild Learning is at the moment (the summer of 1999) a project in the initial phases of becoming a loosely defined network of social workers, bureaucrats, local volunteers, wild youngsters - and researchers. All of these participants are also part of different projects outside WL. These other projects e.g. 'The Street Pulse', 'Ecological Initiators', 'The Gang' etc. are their main practices and they include a variety of agendas and specific ways of doing alternative social work.

The objective of Wild Learning is to work on different levels:

1) The organizational learning connected to the development of social work institutions in Copenhagen;

2) The development of democratic ways of working in solidarity with 'wild youngsters' and thereby change of social workers identities;

3) The change of 'wild' youngsters ways of living through various activities and projects.

These levels intermingle in numerous ways some wild youngsters are trusted with resources, they are slowly given larger responsibility and ends up becoming staff members in projects: To learn social work is also learning a way of living; the learning among the staff is also a mean to institutional development and the 'budding' of new projects brings possibilities of flexibility and change, which are important for projects with development goals and it is also an important social work method. WL will be centered around a structure called The Lodge (see box 3 p. 81).

In figure 1 the Lodge is primarily visible as networks and cooperation between projects (the dotted lines going out from WL). The Lodge is emerging as a network of about 45 participants, placed in a variety of positions (as street workers, volunteers, so- cial workers from the town halls, youth counselors, project workers) and all situated around local communities in Copenhagen. At our research meetings with some of the project participants, discussions took place about criteria for accepting newcomers and actual people who were going to be part of the Lodge. Examples of criteria are that the individuals are 'good' at what they do, meaning that they possess organizational capability, autonomy and flexibility together with an ability to initiate things. They are people with a certain attitude and people who are willing to discuss and develop what they do and help each other. It is stressed that they are 'upcoming people', and not the people in power. Or that they are people working within the selected local areas of Copenhagen, which WL has a special task of developing e.g. collaborating around youth clubs and specific groups of youngsters.

\section{Practice Research in practice}

$T^{t}$ is a central point that doing PR is a practice in itself. It makes it necessary to include methodological reflections on the research as a practice and as part of a broader societal practice. That includes reflections of how to position the research, as part of what interests, who to cooperate with, in what direction the transformation of references are pointing and, accordingly, where the researcher is participating in moving that practice field he/she is cooperating with(in). Making research conditions and practice explicit is an important point to be added to validating research.

Before I go deeper into the theoretical and methodological aspects of what it means to do practice research, I will start with a concrete example of analyzing 'learning resources' together with WL as part of my early practice research project. 


\section{Conceptualizing learning} resources

W

here Morten Nissen focuses on social work methods, the organisation of WL and its discourses (see Nissen 1999), I analyze WL (and projects connected to WL) as learning environments - practical, social, ideological and cultural communities of specific participants with different perspectives, interests and ways of living and participating. A community, a compound of different action contexts (overlapping each other), an environment which composes learning resources and possibilities but also dilemmas, problems, barriers of learning and conflicts. To look at WL and related projects as learning environments brings about possibilities of research on learning in new ways. That means looking at learning and development as you find it among people 'in the wild' so to speak, without primarily focusing on the part that is goal directed, defined and arranged by someone - the parts that are typically highlighted in more institutionalized forms of learning, e.g. schools. My approach has several parallels to the anthropological research practiced by Jean Lave (Lave \& Kvale 1995). Her field work also moves at a 'slow pace', trying to build a holistic understanding of what is happening in the community of interest, pushing for conceptual organization and insight during the field work phases of research (instead of collecting data once and for all) and in that way concretizing the (abstract) research questions ${ }^{6}$.

\footnotetext{
6 But there are also differences: Anthropologists, including Jean Lave, do not cooperate with practitioners with an explicit purpose of making theory to be used in developing their local practice. It is an important part of Practice Research to contribute to the change of practice in a specific direction, changing practitioners' references, their ways of thinking and their actions in practice.
}

"If the enterprise of doing empirical research has any purpose to it, it ought to change your theory as much as your theory informs the empirical work. I see this as a process of going back and forth in an open-ended way so that you keep doing field research and you keep working on your theoretical understanding of the world and hopefully, each of them makes the other better over time." (Lave \& Kvale 1995, p.223)

\section{Box 1}

This way of focusing on everyday life with its concrete situations and human beings instead of abstract procedures and categories has also been one of WL's predecessors' most promising characteristics. At the same time a method and an anti-method.

\section{The beginning of a working process \\ he reason that it has been at all possi-
ble for me to start the construction of
learning resources connected to this} practice is that others, especially Morten Nissen (see Jensen, Mørch \& Nissen 1993, Nissen 1997, 1998, 1999, 2000b), and myself in a previous project (Mørck 1996) have done research within the kind of local culture or community that Wild Learning is part of and grows out of (remember the branch figure 1, presented earlier). I started this conceptualizing of five learning resources using key concepts from critical psychology (in the Copenhagen tradition) and situated learning (the theory of Jean Lave, Nielsen \& Kvale 1999a etc.) to look into written analyses of the pre-history and the leaders description of WL. I am attempting to conceptualize some ideals for good learning environments within this type of practice. In other words it is a construction of WL's practice ideology reconceptualized in my own theoretical terms. Thus being a construction made by me, WL and different parts of the broader network we 
from both researchers and the practitioners we are cooperating with will be visible in the following conceptualization of the learning resources, both as theoretical questions and as practitioners told experiences. This will give you a glimpse of how this PR project is produced in the tension between consistency and relevance (see the feature of 'PR as joint venture'). and developing WL's alternative social practice, which is a continuation of their earlier work in other projects. These projects are working in solidarity with 'wild' youngsters creating the projects with them, offering them payment for the participation in activities so they don't have to continue their criminal activities and offering them both personal support and specific action possibilities and meaningful activities. The research done with these former projects shows that some of the 'wild young people' change their participation and position in the projects and in their life in general, e.g. becoming social workers for other 'wild' youngsters (Nissen 2000b, Malmborg \& Nielsen 1999). That is one example of how these projects in my opinion were able to bend the discourse in fruitful ways (also see the feature on 'critical analysis' later in the paper).

Throughout my research process I will reconstruct the learning resources (and WL's practice ideology) further by discussing my future empirical analyses of trajectories anchored in certain local contexts and theoretical questions related to them. References

7 I have discussed this conceptualization of the learning resources further with practitioners from the community of WL, some people from an ecological project within the same network, and researchers and students in a workshop on a seminar on 'non scholastic network' and on the conference of 'Critical Psychology and Action Research' in Bolton, UK.

8 Aspects related to the learning issue in the neo- liberalistic discourse are analyzed by Bultmann (1998), Mørck 1998a, 1998b, 1998c, also see Nissen 2000a, Nissen \& Clausen 1997.

\section{The five learning resources}

\section{Learning across the contexts of work, education and everyday life}

Work, education and (the rest of) everyday life are areas covering very different types ${ }^{9}$ of action contexts.

The concept of action context (a core concept within critical psychology, see Dreier 1997, developed further by Nissen) is defined as a "we" of certain participants doing "something" together, with certain conditions. An action context is a societal structure of participants, ends and means organized around their accomplishment in action. The content is not determined once and for all, but is getting defined continuously by the participants and by relating to societal totality, build of other action contexts overlapping with different participants ends and means. (Also see Nissen 1997, 1998)

\section{Box 2: Action context}

9 This distinction between learning connected to work, (formal) education and everyday life reflects tendencies in ways of talking about learning: Where 'school learning' or teaching has been the dominating discourse, socalled 'lifelong learning' is now transgressing the boarders to other everyday life and work contexts. These ways of thinking are starting to show and might initiate changes in the dominating discourse (see e.g. UNESCO's World commission report about lifelong learning (Jacques Delors) and OECD paper: Improving Student Motivation for Lifelong Learning, 1999). That is why I highlight this distinction even though, as I will mention later, the distinction has its problems. In other words I will both use and trouble these concepts throughout my research (Lather 1999, p.22). 
We participate in different ways and we learn different things by participating. But we learn in all of the contexts even though learning often is formulated only as an explicit goal in the educational or the teaching context. WL is a special learning environment because it organizes learning across all three types of contexts. WL, especially the Lodge, is talked about as being a kind of education (see box 3). But opposed to typical educational settings WL places the concrete work in different projects with young people in marginalized positions as the most central place for learning. But everyday life experiences e.g. having been a 'wild' youngster yourself, the people and places you know from the street, from political or grass-roots work, are also acknowledged as very important resources in social work. In WL they call it being 'streetwise' (Lihme 1998). A large part of the participating social workers have no or only very little formal education related to doing social work. It is typical for this community to rank this kind of everyday life and work knowledge and experience much higher than formal education. However Wild Learning is also presentations, organized reading of papers, reflections in groups e.g. at research and lodge meetings, things we typically connect with education. But in contrast to typical education this reading and these discussions and reflections are built upon the concrete social work and everyday life experiences of participants and are of no value without being related to it. In this way WL stresses the relevance claim in the 'educational' part of the project.

I have a hypothesis that this special way of organizing learning 'across' different types of action contexts is an important resource if the so-called 'school tired' youngsters or 'wild' youngsters, including the 'wild' social workers are to feel interest in participating in such a learning environment.

\section{What is the Lodge}

1. The main purpose is to secure that Lodge members get better to do their work with the young people and that the general 'work with youth' in Copenhagen thereby gets qualified further.

(..)

4. Members shall mainly work with criminal youngsters or with youngsters in closely contact with criminalized environment.

5. The members shall mainly work directly with the young people. There shall not be overweight of researchers, leaders and the like.

6. Members shall use the Lodge to get a network of good partnerships to collaborate with.

7. Members shall seek to educate each other by sharing experiences.

8. WL provides lectures by good and inspiring persons from outside.

9. A goal for the Lodge is to become a social political factor of power, that can influence the political debate within the youth area.

10. The Lodge shall be the starting point for initiatives of collaboration between Lodge members.

11. The Lodge shall function as an 'experimental platform' for education and active seek to mediate experiences and methods, so others may use them.

12. The Lodge may function as a sort of 'employment service', where you can find new coworkers to your new initiatives.

\section{Box 3: Paper about what the Lodge should be, by WL, january 2000}

Behind the conceptualizing of this learning resource lies a distinction of action contexts into three types. However, the way I use the concept of everyday life here is problematic. I am at this time primarily presenting the term as 'the rest' when you subtract work and education, but work and education are also part of everyday life as Jean Lave would say (Lave in prep., also see Dreier 1999). I need to further define the participants everyday life and projects as something 'in it self' and not just as a residual 
category. This is another example of further theoretical and empirical work needed analyzing how the everyday life of WL's participants may be determined on its own premises.

\section{Learning through a community of practice}

Different professions and trades have what Jean Lave and Etienne Wenger call communities of practice. But how is the concept 'community of practice' combined and differentiated from the critical psychological term 'action context' I have introduced?

Where community of practice (see box 4) primarily is used as a professional technical or special working community of colleagues, then 'action context' is a broader term. In contrast to a 'community of practice' 'the users' and various participants are included in the concept of action context. And the connection within the society, e.g the endmeans relations are more specified within the action context term. On the other hand the concept community of practices is in my opinion very good at capturing how these alternative (wild) social workers and socalled 'resource persons' can share engagement and repertoire even though they are spread across many different action contexts with very different participants, ends and means. In that way the concepts supplement each other and both become important concepts in my framework. It is necessary to be aware of possible contradictions in my further work. You would for instance talk of the teachers' community of practice within vocational schools ${ }^{10}$ but not include the pupils (here it is the actual occupation as a teacher, which forms the border for who is included). However, in WL the borders of defining

10 I am also researching examples of trajectories and learning from the margin within vocational school to put the research on WL in perspective.
A Community of Practice (CoP) - a core concept in situated learning theory, by Lave \& Wenger 1991, Wenger 1998 - is not only a practice community of e.g. the blacksmiths, the carpenters, the pedagogues, sharing certain knowledge and skills, but also a set of relations among people, activities and world over time and in relation with other overlapping communities of practice. The community of practice has three characteristics: First the source of coherence in a community is the mutual engagement of participants. What makes engagement possible and productive in practice is as much a matter of diversity as homogenity. The mutual engagement is partial, it involves complementary contributions and competencies might be overlapping. But the term community should not assume peaceful coexistence and mutual support - there may be plenty of disagreements, tension and conflicts within a practice community. Secondly; in the community the members negotiate their joint enterprise. This involves that the different participants may have many different purposes for participating in practice; e.g. earning a living, working for a 'cause', aspiring to have a good life etc. Communities of practice develop in larger contexts - historical, social, cultural, institutional - with specific resources and constraints. Negotiating a joint enterprise is also negotiating accountability, including what matters and what does not. A third characteristic of a community of practice is the development of a shared repertoire, which includes routines, words, tools, ways of doing things, stories, gestures, symbols, actions or concepts the community has produced or adopted in the course of its existence, and which have become part of its practice. (Wenger 1998, chapter 2).

\section{Box 4: Community of practice}

who is part of the community practice are much more fluid involving a lot of different participants and projects. In that context you might include 'wild youngsters' in the community of practice as soon as they themselves or others perceives them as being 'resource persons' in some way. This is another 
example of the theoretical and empirical work I have to continue working on, to get closer to consistency.

To become part of a practice community is closely connected to a change of identity. Identity in practice arises out of interplay of participation and reification ${ }^{11}$. As such identity is not an object or an essence but $a$ constant becoming (Wenger p. 153-154) contextualized in the individuals various action contexts.

In WL the participants' identity will become closer connected to WL's community of practice, when the Lodge and other activities begin to form, when they start developing joint enterprises and shared repertoires. Because WL is a new practice community presently starting up and organizing itself I suppose that people from the community will bring with them repertoires from their other projects and action contexts, and in that way influence what WL is becoming. The learning process within the practice community will be going in two directions: The participant is acting as part of $\mathrm{WL}-\mathrm{a}$ process of identification with the repertoires there, getting support from the other participants and projects; and at the same time the participant is taking part in WL's constitution and giving WL new meanings (see box 5).

Throughout the project I will analyze both the constitution of the practice community and the concrete changes of some individuals and specific projects. I will be trying out how these theoretical terms grasp practice and where they fail or involve contradictionary analysis.

11 Reification refers to the process of giving form to our experience by producing objects that congeal this experience into "thingness" (Wenger 1998, p. 58). The acknowledgement through being a 'member' of the Lodge and presenting at a Lodge meeting are examples of a process where identity as a 'good social worker' is reified (see also box 5).
Kevan is in his mid twentys and one of the younger members of the Lodge. He is one of the former 'wild' youngsters from the Nørrebro area who used to make a lot of 'shit' with friends on the streets. But he has changed. The last couple of years he has been employed as part of the local municipal 'youth team', first mainly working on the streets and in 'The Street Pulse' - an 'in place' for young male immigrants. The last half year he and some colleagues have increased co-operation with a local school. Kevan has been working with an 'examination class' together with a teacher and five youngsters. The youngsters was placed in this alternative class because they were 'terrorizing' the school. None of the teachers dared to have them in their classes but the school did not want to throw them out either. Kevan feel this experiment has been hard and full of dilemmas. But at the end, when the youngsters managed to get their examinations, he thinks more positively of the project: Kevan proudly tells how they are to start at vocational school where he will follow and support them further if they run into trouble.

At a Lodge meeting Kevan is asked by the leader of WL if he would like to talk about these activities at a future meeting and Kevan says yes. (Being asked to present is a big acknowledgement of your work and it is also a big challenge to stand up and present your work to about 30-40 social workers where many are 'old-timers').

This is an example of how former 'wild' youngsters and newcomers may bring new meaning (about co-operation with schools) to a field, which has mainly consisted of street workers not co-operating closely with the schools. It is also an example of how certain projects, here 'The Streetpulse', are 'budding' with new activities.

Box 5: Kevan; changing identity and bringing new meaning to WL (summer 2000)

\section{Learning through budding projects}

As seen from figure $1 \mathrm{WL}$ is the latest 'branch' or 'bud' on a 'tree-like' development composed from a lot of previous projects and from different existing projects. In contrast to more established, formal or social institutions, which mostly are anchored 
in a specific place and building with fixed goals and education plans for students to follow, this kind of 'project budding' practice is much more looser and more 'moveable'. It is fluid whom and what WL and the connected projects are as well as how you participate there.

I see it as a special resource for a learning environment that the action contexts are able to change with its participants. It is also changes according to specific conditions and possibilities. The changes happen both on a large and on a small scale. On a larger scale the whole project might be changing it's name, what it tries to accomplish, the participants and the ends-means relations (e.g. the change from 'The Wild Young' to 'Wild Learning'). On a smaller scale certain projects might be budding with specific arrangements and activities, e.g. alternative school projects (see box 5), concerts, youth conferences or a gym. It follows that certain 'wild' youngsters, 'resource people' and other participants plan and take the main responsibility of carrying these activities through. Within other practices with a desire for flexibility the way of 'project budding' is becoming a special quality that organisations want their employees to possess (e.g. Youth schools working with youth democracy want employees to be facilitators of the young peoples' activities, Mørck 1998a).

I will be researching concrete examples of how this kind of environment within and around WL creates possibilities and barriers for newcomers and wild socialworkers to share responsibility and be able to change positions and in that way be part of the constitution of practice.

\section{Networking: Developing connections across contexts}

In traditional education learning is often organized in a very individualized and competitive way and is bound to take place in certain rooms, classroom within schools, which are again isolated from other practices. If pupils or students are helping each other it is often considered as cheating (see Varenne \& McDermott 1998).

Within and around the community of WL you work together with others and it is very important to maintain and extend the network of the projects to give the specific arrangements power, in order to do something for the common cause, to better conditions for young people in marginalized positions.

At the research and Lodge meetings the participants spend a lot of time on what they call 'gossip', asking where certain people are now, what they are doing, getting up to date on the possibilities within their network. The organisation of WL - the combination of participants from different projects and places within the system and parts of Copenhagen - is another way to develop connections across contexts, and thereby to better the possibilities for doing the work.

\section{Learning through trajectories; change in participation and position}

A very central part of my research project is to analyse the changing participation and position of 'wild' social workers within the project and in their life situations: 'Following' social workers and 'resource persons' who in different ways have 'wild' backgrounds. This is a part of the PR features, which I later will discuss as 'decentered analysis'.

The predecessors of WL have been characterized by a high degree of 'fluid', and flexible positions, which implies good possibilities for the youngsters to change participation and position within the action con-

12 But there are also exceptions and places were this School Discourse is blurred, acknowledging that it is important to be able to co-operate, e.g the Danish tradition of 'project work' (Berthelsen, Illeris \& Poulsen, 1985). 
outlines-2000.qxd 23-11-00 12:55 Side 71

texts of the projects. This is a great contrast to the established educational system characterized by fixed positions, set tasks, and differences in responsibility for the teacher and the pupil.

\section{Change in position and participation for 'The street-kid Jeanette':}

Jeanette, a 16-year old girl with heavy drinking problems became an activist in "The Gang". Very soon she was overwhelmed with solidarity that she should save a boy she fell in love with from heroin addiction. Jeanette was then supported (by the project) in understanding her relationship to him in terms of help - that is in terms of the organization. When he finally broke up with her - very violently as it turned out - she was able to interpret that incident in the generalized framework of "The Gang's" lack of ability to provide for people with problems like his. Her personal trauma was generalized in the collective discussion of this problem. Shortly after she met another man, became pregnant and announced that this would mean the turning point, the point were she would quit drinking. Jeannette's situation became one of the important reasons for planning a new project activity centered on infants, small children and their mothers. In this activity she was able to engage herself as a 'resource person'. (Nissen 1999, p.8).

Box 6: The street-kid Jeanette (by Nissen)

This part of my project is aimed at developing the concepts of movement and change in the life of wild youngsters and social workers. Dreier (1997) suggests concepts of trajectories and life conduct. As you will later see, I think these concepts fail to put the question of changes in societal position in the foreground. I am therefore suggesting to differentiate the concept of trajectories into three analytical levels: Societal position, participation within action contexts and life course - an analytical tool, which I term 'The Life Portrait'.

Throughout this research project I will keep re-working this analytical tool; how is it grasping or failing to grasp the movement of social workers and 'resource persons', who are positioned and participate in different ways in projects connected to the community of Wild Learning. From a decentered analysis of their everyday life I want to highlight for whom these 5 learning resourses is actually resources in their life? And how do the participants get access to the possibilities these learning resources bring about or what are the barriers and reasons why they don't. In other words I want to use these five learning resources as hypothetical focus points, which will change to a certain extend with the further research.

When I introduced this part to the leader of WL he responded something like: "You can't be certain that these learning resources will be visible as resources in all these people's learning". However, when these analysis of mine are going to be discussed throughout the joint venture it will bring focus to what this means for these people, how are their ways of participation changing, what are their positions, and what are their reasons to move in different directions, etc.

I will be contributing with questions like: Why are these specific people (e.g. 'Wild girls' ${ }^{13}$ ) benefitting to a lesser extend from these learning resources? Does the practice and ideology need to be revised, or do the community of WL (and the specific projects) have to be more aware of how to include some of the wild youngsters in peripheral positions - and their learning resources. This is an example of how I am

13 When I at a research meeting (year 2000) mentioned that I would like to 'follow' at least one 'wild girl' - 'resource person' or social worker - with different ethnic background, the participants to their own surprise could not point to any I could follow, even though they worked with several 'wild' female youngsters with differing ethnic backgrounds. For some reason within this community the trajectory from being a wild girl to becoming a social worker, was much harder to build and move along. 
contributing with a critical analysis and how I might be participating in developing practice.

\section{PR in theory and metho- dology}

$\mathrm{D}$ oing practice research within the tradition developed at Copenhagen University during the 90's means to use and develop critical psychological theory and at the same time participate in the development of the practice you are doing research with. Some of the most explicit writings on ways of doing and conceptualizing practice research is by Ole Dreier and Morten Nissen, who have developed slightly varied understandings of practice research (Nissen 2000a). I will briefly try to highlight what I see as the most important characteristics of critical psychological practice research. On the basis of Nissen's and Dreier's work I will point out some similarities and differences between these theories and discuss them exemplified by our practice research project with Wild Learning, and through this discussion try to contribute to the understanding of practice research further.

\section{The relation between theory and practice}

$\mathrm{D}$ reier (1996) wants to bridge a widespread gap between theory and practice, by replacing where and how researchers do the research. Instead of working in an isolated research environment at a university and afterwards transferring the results to others' practices where practitioners are supposed to use the findings, he argues that researchers should do the research in the center of the particular practice they are researching. In that way PR is a participant oriented research, which tries to democratize research. PR is an attempt to extend the pos- sibilities that research may offer. It has evolved from the criticism claiming that other forms of research fail to grasp certain features of practice; e.g. substantial reasons why practitioners act as they do. Researchers theories serve as tools for analyzing problems and possibilities in practice. The outcome of practice research is theories about how specific local problems and possibilities are aspects of certain structures of the action contexts and how practitioners may handle the problems and extend the possibilities. These findings are analyzed in a way that enables them to be generalized and used in other similar action contexts with similar problems and possibilities. The generalization is a hypothetical claim and it is supposed to be valid when certain structures are present in the action contexts. Because it is an analytical pointing at a practical possibility, it is a 'thought possibility'; visualizing a possibility that the practitioners without the research would have failed to see. The demarcation and the relevance of the research problems are made on grounds of the specific practice, not on some abstract science criteria or interest (Dreier 1996, p. 130-133).

In Dreiers conceptualization of PR there is a tendency to position the researchers as servants to practice. He primarily pinpoints how the research is good and useful for practice. And he does not mention that researchers have specific scientific interests e.g. in developing certain concepts and theory, or in analyzing and criticizing the dominating discourse within a field (both issues that also are an important resource in his own work, e.g. Dreier 1997). I think it is important to highlight these issues. Mainly because this is one way where the critical psychological tradition of practice research in my opinion have some important strengths compared to other pragmatic forms of action research (e.g Stringers 1999 based on con- 
outlines-2000.qxd 23-11-00 12:55 side 73

structivist philosophy, see also Mørck 2000). But also because it is important not to paint too harmonic and nice a picture of the co-operation between researchers and practitioners. These interests of building theory and criticizing discourse may seem very abstract and not immediately useful from the practitioners point of view. For these reasons, it is important to differentiate the researchers interests more explicitly from those of the practitioners. But naturally there are not only differences in interests, - to have a reason for co-operation there must be some common interests.

\section{$P R$ as joint ventures}

$\mathrm{M}$ orten Nissen (e.g. Nissen 1997, 2000a, 2000b) is more explicit on this point in his conceptualization of PR. He articulates PR as a joint venture between researcher and development project, co-operation between two parties who each have their project and interests. Both parties contribute to the joint venture and both parties make use of it. The practitioners contribute with their experiences and thoughts. The researchers contribute with their theories (systems of concepts) and knowledge from other areas. Thus both the theories of the researchers and the experiences of the practitioners will change; Nissen calls this transformation of references.

To be more specific, what do researchers and practitioners get out of the joint venture and the transformation of references?

In the beginning of a joint venture the researchers' theories might seem vague and not very concrete to the practitioners. This to some extend holds for the theories and concepts presented at present in this paper. But after a while the meaning of the theoretical concepts will become more clear as they are used in written and spoken analysis of the practitioners' experiences (see the fig- ures and boxes showing analysis one year further in this process). The theories become empirical and relevant for practice. In this respect it is also a goal for empirical research to be consistent in the PR tradition; the concepts have to be determined in relation to other concepts and the analyses and the theoretical framework have to be free from internal contradictions. The practitioners in the joint venture get empirical analyses; new concepts and views that offer the possibility to reflect on their own practice in new ways. This can for example help them estimate what parts of their practice they want to stand by and strengthen and what parts they wish to change. It can also help them to put words to what they do, why they do it and what meaning it may have. But this is only possible if the the researchers' analysis are relevant i. e. point to specific conditions that have meaning to the participants in practice and to conditions that are possible to work with and hopefully make changes for the better. This is the PR goal of relevance.

But it is not only the practitioners learning from the joint venture. Besides our learning about the field and its methods we (researchers) also get the chance to try our theoretical concepts at work: How and when are the concepts usable? Where do they fall short? What parts of the theories need further development and are there parts the researchers have to give up? Thus the theories change throughout the joint venture.

\section{The work of the research communities}

$\mathrm{H}$ owever, to work in practice trying to promote consistency and relevance involve contradictions and is a never ending task. That is why researchers are not only involved in a joint venture with practitioners, you also need a kind of joint venture with research communities working 
in itself, transgressing the tendency that it is only a residual concept defined for what it is not: the Scholastic learning (see also Nissen 1999, s.18).

Let me return to the initial question about what PR is and to whom. The analyses and the generalizations of possibilities and learning resources within and around the projects connected to WL could fairly easily cover common interests between the practitioners of WL, the specific projects, and myself. But the more abstract theoretical 'nonscholastic learning' interest of mine has not derived from an interest formulated by the practitioners. It is rather an interest derived from my research network of non-scholastic learning (see e.g. Lave 1999, Dreier 1999, Nielsen 1999 and Østerlund 1999 in Nielsen \& Kvale 1999). In that sense this somewhat abstract question only partly overlaps with the interests of the practitioners. Still, the overlap and the common interest in alternative learning has already developed since our first meeting with the key person in WL. For instance he decided to call the project "Wild Learning" after having read the first papers about our research interest and projects. In that way learning has become a more central aspect of the project than it was to begin with.

But how much and in what ways the practitioners will find this (more abstract) learning part of the joint venture directly relevant for their practice, is a question that will be concretizied through our further joint venture. As you see in box 7 my Ph.D. project has changed focus and design several times already - changes covering a progress towards more common interests across the contexts and participants involved.

\begin{abstract}
14 The theoretical goal and the goal of practice development, the relevance and the consistence problems, are closely connected, and it's not possible to do the one without the other. But as a researcher you may position yourself in a different way. Some researchers are working 'closer' to the practice being researched within, pointing to relevance problems and empirical use of concepts, and others are mainly doing theoretical discussions and further theoretical development (e.g. philosophers very rarely work directly with empirical projects).
\end{abstract}

15 Wackerhausen (1999) differentiate between a scholastic and other non scholastic paradigms, where the scholastic paradigm is taking over in our time within the field of learning institutions. 


\begin{tabular}{|c|l|l|}
\hline $\begin{array}{l}\text { Summer } \\
1998\end{array}$ & $\begin{array}{l}\text { Everyday life } \\
\text { and learning } \\
\text { across contexts }\end{array}$ & $\begin{array}{l}\text { 5 pupils from vocational school } \\
5 \text { wild youngsters from WL } \\
\text { selected by criteria of difference in position, participation, gen- } \\
\text { der and ethnicity }\end{array}$ \\
\hline $\begin{array}{l}\text { Spring } \\
2000\end{array}$ & Wild learning & $\begin{array}{l}10 \text { participants from the community connected to WL (primary } \\
\text { social workers) } \\
\text { selected by criteria of difference in position, participation, gen- } \\
\text { der and ethnicity }\end{array}$ \\
\hline $\begin{array}{l}\text { Summer } \\
2000\end{array}$ & $\begin{array}{l}\text { Learning from } \\
\text { the margin }\end{array}$ & $\begin{array}{l}1-2 \text { pupils with other ethnic background than Danish from voca- } \\
\text { tional carpenter school (both former 'dropouts') } \\
\text { about } 8 \text { from the community of WL, all with 'wild' backgrounds }\end{array}$ \\
\hline
\end{tabular}

Box 7: Changes of working title and design during the first two years

\section{Decentered analysis}

$\mathbf{I}^{\mathrm{B}}$ n Dreier's (1996) conceptualization of PR he stresses the importance of analyzing practice not only from the perspective of the professionals but also from the perspective of the users. On the basis of his own research within health practice Dreier (1996) points out that there are surprisingly big differences in varous parties' perspectives. Therefore, he argues the PR goal must be to analyze the users' understandings, standards and concrete use of practice and relate it to the other parties and their understandings and standards. This new understanding shall be used to give the change in health practice a direction (Dreier 1996). When Dreier talks about the user perspectives being overlooked he does not mean that you should just analyze the users' evaluations of the practice. He understands 'user perspectives' in a broader sense, including analyses of the different ways they use practice and relating it to their participation in other life contexts, their personal conduct of life and life trajectories (Dreier 1997).

In my design I select certain contexts and participants whom I 'follow' more closely (se box 7) with participants observation and in-depth group-interviews. I am very inspired by Dreiers work even though I hesitate to use the term 'user perspectives' as I do not want to position the participants as 'users'. Instead I analyze different participants perspectives in different positions. Participants who are all in different ways learning something. And I encourage them to point to how they participate, e.g. in the vocabulary of WL as 'resource person' (being an important resource in the work, not yet employed as social worker) and as actually employed 'social workers'. In the community of Wild Learning some of them will be part of the Lodge, others will be connected to various specific projects in other ways, e.g. as wild youngsters who are starting to help others and thereby becoming resource people. So even though I am not analyzing 'user perspectives' I will still use Dreier's (1996) methodology of how to get insight in participants' perspectives anchored in everyday life, because I also want to get perspectives of practice 'from the outside'. Or in Dreier's words doing 'decentered' analysis of practice. As Dreier (1996) suggests I will be contrasting different perspectives connected to these practices by analyzing 'wild' 
social workers participation in other action contexts in their everyday life and their movement across these different contexts. Constructing practice in this way will give an important supplement to e.g. Nissens analysis of methods, discourse and practice ideology, including my own analysis of learning resources in connection to WL.

Learning as trajectories of participation:

'Learning can be understood as part of subjects' moving, changing participation across the multiple contexts of their daily life." (Lave 1997).

"This [trajectories] singles out certain kinds of changing participation: the notion of movement in a direction, of the possibilities of going deeper, becoming more of something, doing things differently in ways that gradually change the way you are objectively, the way you are understood by others, and the terms in which you understand yourself to be a socially located social subject. Trajectories are made and made possible in ongoing relations of participation in practice." (Lave 1997).

\section{Box 8}

\section{'Movement', trajectories and learning}

$\mathrm{B}$ ut how is this 'movement across' related to learning? Jean Lave among others has introduced a socially situated theory of learning, whith which you can talk about learning without reducing it to simple mental tasks or problem solving but rather in more recognizable terms about human projects, which in many ways fits nicely to the theory of critical psychology.

This concept of trajectories (developed by Lave 1997, Dreier 1999 and Wenger 1998 among others) highlights the important movement 'across contexts' and the movement 'across time'. But in my opinion the theory falls short in bringing the movement 'in societal position' to the foreground, a movement that is very central when re- searching 'learning from the margin'. To counter this lack I am working on the analytical tool I call 'The Life Portrait' (see Mørck 1996). I will try briefly to exemplify how the Life Portrait is used by analyzing changes in Ramid's life situation (figure 2 and box 9).

In the case of Ramid you see a movement in societal position. In his re-production of action potency together with a group of friends, and 'The Gang, and later with 'the youth team' they manage step by step to enlarge his and other ethnic minorities' action potency by writing recommendations to better ethnic minority teenagers' conditions by discussing it with different parties and by doing activities and projects with youngsters. This change in participation takes place within and across Ramid's different action contexts: First mainly on the street as part of the everyday life there, then he participates more organized as a voluntary in 'The Gang' and later he also participates as employed social worker in the town hall. Through these activities and their own change in participation he and the others have succeeded in the struggle to get paid job positions helping others in marginal positions. Ramid ends up in a position in WL where it is his job to take part in the more general development of social work: Among other things it is his task to spread these kind of activities and action possibilities to a larger group of wild youngsters. Thereby he moves across time and his life course from being a teenager (where his participation and networks among the criminal and wild youngsters is seen as a 'societal problem' by local authorities), to a position as a respected social worker. In this process his networks within ethnic minorities on the streets is turned to being a (learning) resource; action possibilities he uses in his work. The life orientations of Ramid (figure 2) reflects that Ramid's life may still take some major changes when he in the future might pursue interests of finding a wife, securing his mother's happy old days and / or trying to take an education, which will be a secure base if he and his family decides on moving to Morocco.

Box 9: Ramids movement across societal position, action contexts and life course 


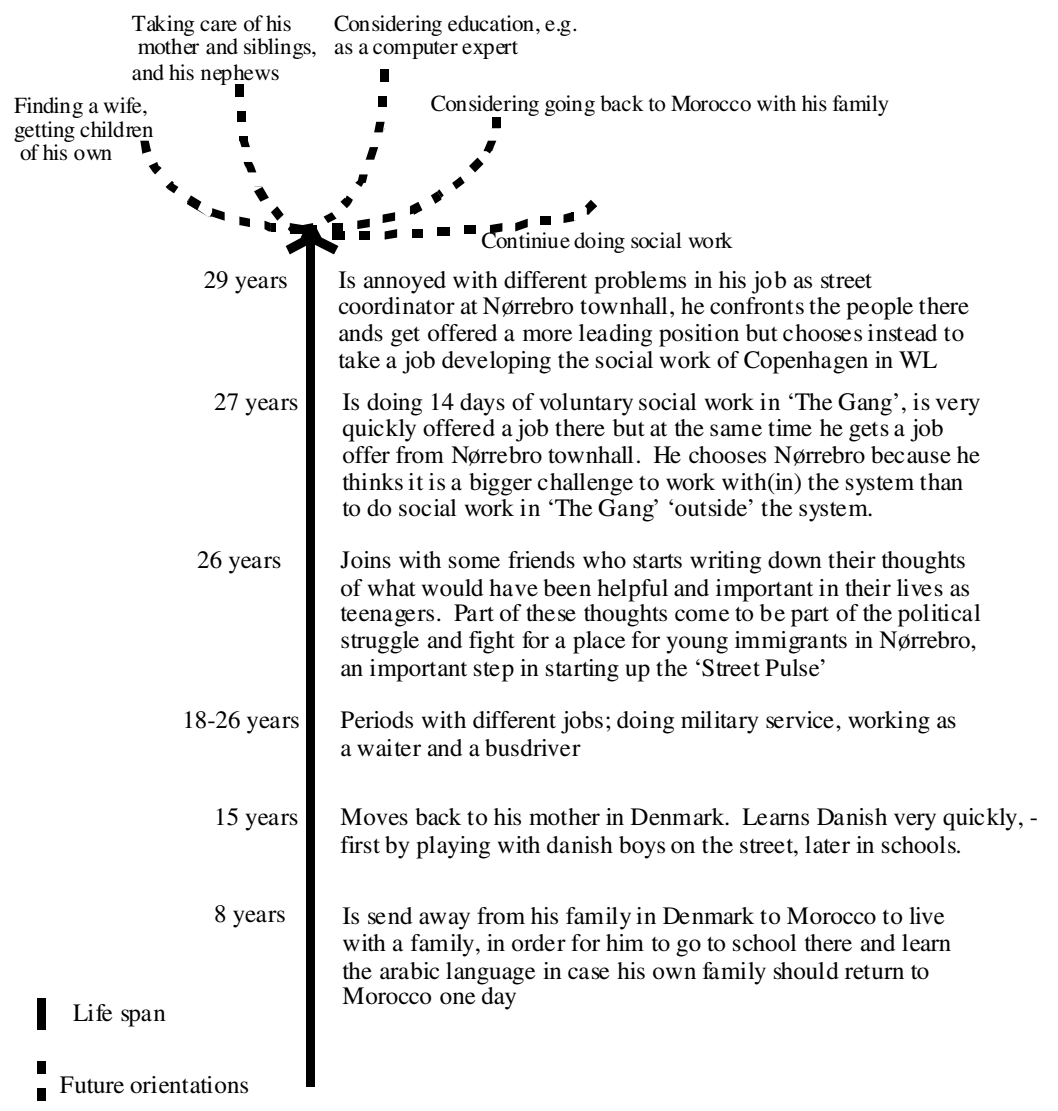

Figure 2: Ramid, an employed social workers at WL; doing, learning and developing social work

1. Societal position: The concept of position sums up the action possibilities of the individual by accentuating the aspect of the life situation, namely how the relation between her contribution to and the re- production of her action potency is organized through societal production (Holzkamp 1983; 196, my translation). Holzkamps' concept highlights how the life situation is societally pre-structured across the different local action contexts and thereby how the (societal) individual is part of society.

2. Participation within and across multiple action contexts. This aspect points to changes in participation within a persons multiple action contexts as part of his/her conduct of life (see Dreier 1999, Lave 1997).

3. Course of life. The present life situation is related to a past and a future. Personal development is in general understood as including conflicts. The direction and course of a life is not straight forward but a contested, zig-zagging one, marked by progressions, retrogressions and contradictions (Dreier 1997; 27). That is why e.g. events and experiences from the past change their meaning to the person depending on the actual life situation and the standpoint (in present time) from were it is looked upon. In other words it's a process of continuous recontextualizing of meaning. The important 
and acting within a field of practice, the fun-

changes in the view upon the past and an imagined future gives a sense to where the specific person is right now in his actual life situation. What is his or her interest and specific life orientation? What are meaningful activities for her and how does she imagine her future?

These three aspects implies and are realized through each other, and they should not be understood as separate entities but as tools to analyze changes in life situation.

\section{Critical analysis}

$\mathrm{A}$ fter the first point of PR as joint venture and the second point about decentered analysis, a third important feature is about doing 'critical analysis'. Because of the limited size of this paper I will not go into depth with this feature but only outline how combining different ways of analysizing practice can strengthen the critical dimension.

Nissen argues for a practice concept that unfolds in two theories, which each handle a side of practice. One is the ideological, critical discourse analytical understanding presented by Foucault, which highlights the general structures where the relation between the participants, the object, ends and means can be organized within. In this understanding nothing is taken for granted not even who the subjects in practice are and every component is moveable. The other theory of action contexts by critical psychology captures how self-reflecting subjects constitute and develop in interaction with each-other in multiple local contexts. (Nissen 2000b; 34). This second understanding of practice has already been introduced.

In Nissen's understanding discourse is the fundamental structure of ways of thinking damental rules for what's allowed to be spoken of and how (Nissen 2000b; 35).

In my analysis I try to work with the discourse on three levels because I want to capture how discourses may change through practice. Figure 3 represents the formation of discourse and the relation to what I call the practice ideology of the action contexts, e.g. WL's, and the individual ways of thinking, e.g. the participants within WL. It encloses three analytical levels: 1) A societal level of Discourse, 2) an action context level of Practice ideology and 3) an individual level of Ways of thinking. In practice these levels will be closely interconnected and inseparable.

An example: The modern discourses of learning and individuality e.g. the discourse of 'user influence' and 'responsibility for your own learning ${ }^{\prime \prime 6}$ constitutes concrete action contexts and positions 'learners' in a specific way. These are changes that some researchers e.g. Bultmann (1998) understand simply as forms of neo-liberalism. I understand it a little broader as you will see, even though I think it is very important to maintain a scepticism about these changes and how these new words, which sound very positive on the surface, may involve more invisible forms of marginality and exclusion (see also Mørck 1998a, 1998c, Nissen \& Clausen 1997). As a researcher I am part of this discourse production both criticizing it but also using it and trying to 'bend it' / transform it in fruitful ways. You can say the same about the participants within a local practice such as WL - they are also active co-producers of the discourse. In co-operation with others they reproduce and use the discourses in specific ways. E.g. the practice

16 This can also be placed within the discourse of 'the active society' promoted by OECD, see Nissen 2000a. 


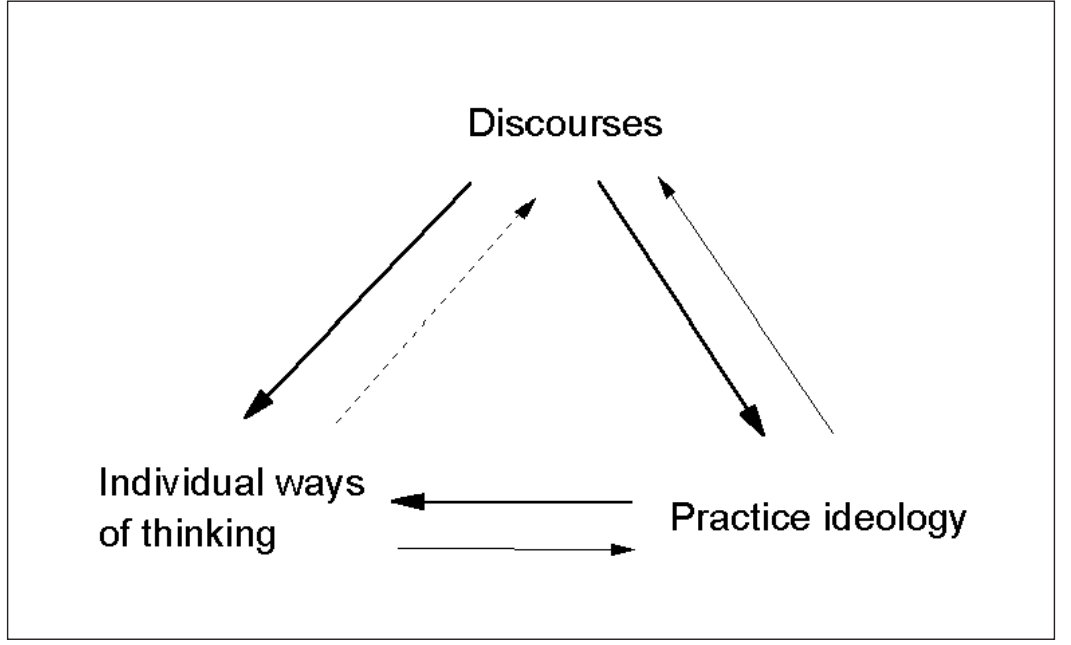

Figure 3: Formation of discourse

ideology of 'The Learning Resources of WL' is not something that is already present and that we as researchers can find once and for all. In this understanding it is something we construct and reconstruct together in the joint venture. But sometimes the local practices are powerful enough to use and transform the discourse into a new fruitful form of practice helped by the media, researchers etc.. The experiences and acknowledgement of the previous projects (remember figure 1) serves as premises for how it is possible for a project like WL to have an explicit goal to reform and develop social work in Copenhagen. Thus concrete practice might bring new meaning to and transform the discourse so other projects and institutions within the field start changing in a certain direction.

\section{Reflections on ideals, problems and dilemmas}

$\mathrm{M}$ $\mathrm{y}$ description of PR might, like many other presentations on researchers' own research, theory and methodology, tend to be kind of idealized. It may sound like PR is 'the best' way of doing research and that all the specific practice research projects mentioned always live up to these ideals. But I am sorry to say that is very seldom the case. Concrete projects are full of dilemmas, conflicts and compromises, like all other practices. There are no happy endings where your research fulfills ideals e.g. of being consistent with no theoretical contradictions, where research is so relevant for practice that it 'transforms' into clear non-contradictionary actions in practice. And even though I think practice research is a very good way of doing research, there are problems and dilemmas within the practice research projects I have participated in and times when they did not live up to the ideals presented here. I will finish this article by reflecting on two important dilemmas within PR: Namely the problem of anchoring the research project and the balancing of critique and action possibilities in the analysis presented back to the practices you cooperate with. There are also other dilemmas e.g. connected to the process of selecting parties, meaning who do you include and who do you exclude from the joint venture as it is impossible to include all relevant parties. Another important topic is about 'language problems' aris- 
ing when researchers meet with practitioners where some may not have any formal education. But these reflections have to wait because of the limited space.

\section{Problems of anchoring the research project}

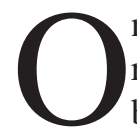

ne important problem is how you as researcher ensure that the research being done is anchored in practice. This means that the research actually 'makes a difference' in practice and that it is a lasting development and not just disappears with you when you as a researcher leave the practice.

It is my experience that it is not easy to get a joint venture going, a joint venture where both parties are engaged and where actual changes in practice come about as a result of the joint venture. There may be different reasons for the limited anchoring: From my experiences with 'The Project Company' (mentioned in figure 1) I know that it can be an important limitation if the project has to fight to get money for survival. 'The Project Company' was because of its 'uncertain situation' especially interested in working on changes and analysis that here and now might legitimate their practice to the funding municipal authorities. Their engagement in my analysis of different trajectories and 'life orientations' among unemployed people was limited, perhaps because it was an analysis that problematized a ruling agenda of the authorities instead of being a straight forward 'method' that immediately would convince the funding authorities that this practice had to continue its work. My thought was that these alternative life orientations might be used as continual arguments every time 'The Project Company' were in contact with different parts of the authorities and that they in the long run may widen municipal understand- ing of the very different life situations and perspectives of unemployed people. And in that way broaden the conditions for alternative practices like 'The Project Company'. I have myself been able to use these analyses in discussions about policies within a broader area of unemployment projects and youth projects I have been working with, since then. But the leader did, as far as I know, not use the results of our joint venture in that way. The practitioners' and assistants' engagement was also limited to readings and discussions of my text. In that way our cooperation in some ways looked like a qualitative method project where I did interviews and discussed them with the particular 'assistants' or informants along the way and then finally in the end of the project produced a report, which I again discussed with the leader and a few others. Thus a co-operation that did not lead to much change back then within that specific practice. At least that is my impression when I look back.

Compared to this the communities of Wild Learning are rather special as WL has a secure economical base for the next three years (and maybe even permanent) and more importantly that the leader is taking WL's goal of practice development very seriously; demanding that we 'give something', e.g. analysis and reflections back to the practice continuously from the start and throughout the research process. So the participants have a chance to reflect and define the content of the research with us and take part in changing it if they do not find it relevant for their practice. These expectations from WL are one reason that I believe there will be far better possibilities to anchor the research in their practice. Another reason is that this joint venture is a co-operation that has been spread and continued over a long time. We researchers are not starting all over again from the start within this area but have analysis and experiences from former pro- 
outlines-2000.qxd 23-11-00 12:55 Side 81

jects, which to a certain extend are relevant for the current contexts. And some of the practitioners have experiences with us, and our former research as well.

\section{Legitimation vs. critical analysis}

$\mathbf{M}$

ost professionals are in some ways dependent on researchers' acknowledgement or legitimiation of their practice. In several practice research projects I have joined, I have met the dilemma between legitimation and critical research. As I mentioned above the analysis of the practice as discourses is one aspect of critical analyses. This way of twisting and making questions to what is spoken about, e.g. reflecting how professionals talk about the users, is not always met with enthusiasm from the practitioners (see Mørck 1995). That might also count for the analysis 'from the outside' where you interview participants on the border of the practice, e.g. pupils at the point of dropping out of school, apprentices that could not get a trainee job outside school or girls learning and working within a male trade. Those are all participants who, because of their (in some ways marginal) positions, might have another (more critical) perspective on practice. These are examples of some of the participants I have been interviewing from the Danish dual system at the vocational school and because of this I expect that my analysis of the dual system have many critical potentials. But how do I present these critical analysis results in ways that are constructive so the professionals will listen and use it, so the analysis has a chance to contribute to change?

One way is to try to highlight the common cause that the research is part of, and pointing to my interest of solidarity for a cause instead of non-constructive criticism pointing nowhere. Within the dual system this common cause I can point to is e.g. the explicit goal of inclusion, which is a main goal of 'Reform 2000', a developmental process that Ministry of education has just started in all Danish vocational schools. Teachers and leaders are right now working hard to change the practices of the schools in a direction of more flexibility, individual choices and inclusion. It is my impression that they do not feel very prepared for this change, because they do not have practical examples to follow nor much extra time or resources to discuss and work on ideas for the change. And at the same time they have to live up to the same kind of evaluation (through exams) as they did before. I hope that my analysis of the young peoples different participation and their perspectives on problems and possibilities within their practice may help find a productive place in this time of change.

In that way it is always an important challenge to balance the proportions between action possibilities and critique when you present the analyses to the practitioners. I hope my co-operation with Nielsen \& Kvale who are doing research in the same area but from another angle (they are interviewing apprentices who already have a trainee job within a working place outside school, see Nielsen \& Kvale1999b) will ease this challenge, because their research especially points to many of the possibilities within the existing dual system. That is one example of how researchers' work can be complementary and useful to each other.

\section{Wild research}

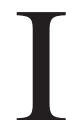
$\mathrm{n}$ this article I have presented and discussed aspects of practice research from different angles: First an illustration through a presentation of WL's and my own current conceptualizing of learning resources, then mainly as theory and method- 
ology, then finally through discussions of two dilemmas when doing practice research. When you present methodology and theory it has an inherent tendency to look nice and tidy without contradictions or problems. I have tried to shake this idealised picture a bit by presenting some of my research in progress, pointing to how practice research itself is a practice done in co-operation with other practices, including a lot of practical and theoretical concerns on the way. In this way practice research is a process where the researcher's first research design will be changed and reworked in co-operation with the practice she is doing research with according to both practical conditions and goals of consistency and relevance. This is a major difference to e.g. survey research where you make your questionaire once and for all. Or experimental research where it is an explicit goal for the researcher to "control' the experiment and a failure or at least problematic bias if you can't. I have to some extend compared PR with other kinds of qualitative research, suggesting that in some practical research projects the difference will not be great as it may be hard to get a joint venture going where both parties are engaged in setting the agenda. In other cases there will be major differences, especially in the ways both researchers and practitioners are participating - using the common project to achieve ends in each of their practices, and therefore trying to point the joint venture in different directions. This kind of research is both exciting and challenging, because when the researcher is not the primary person in control you cannot know where it will go. In that way wild learning hasn't been the only topic of this article, it is also about the potential wildness of practice research.

\section{Literature}

Berthelsen, Illeris \& Poulsen (1985): Grundbog i projektarbejde - teori og praktisk vejledning. Unge Pædagoger.

Bultmann, T. (1998): Bildungspolitik im Neoliberalismus. In Fried, Kaindl, Markard \& Wolf (Hg.): Erkenntnis und Parteilichkeit. Argument.

Dreier, O (1993): Psykosocial behandling. Dansk psykologisk forlag.

Dreier, O. (1996): Ændring af professionel praksis på sundhedsområdet gennem

praksisforskning.p.113-140. I Jensen, Qvesel m.fl (1996): Forskelle og forandring - bidrag til humanistisk sundhedsforskning. Philosophia.

Dreier, O. (1999): Læring som ændring af personlig deltagelse i sociale kontekster. I Nielsen, K. \& Kvale S. (1999a): Mesterlare. Laring som social praksis. Hans Reitzels Forlag.

Dreier, O. (1997): Subjectivity and social practice. Aarhus: Center for Health, Humanity and Culture.

Fahl, R. \& Markard, M. (1999): The Project “ Analysis of Psychological Practice” or An Attempt at Connecting Psychology Critique and Practice Research. Outlines - Critical Social studies, 1999.

Holzkamp, K. (1995): Alltägliche Lebensfürung als subjektwissensschaftliches Grundkonzept. Das Argument 37(6), 212, 817-846.

Holzkamp, K \& Markard, M (1989): Praxis Portrait, Forum Kritische Psychologie 23, p.5-49.

Huniche, L. (1997): De ubegribelige Unge. En analyse af kulturbegrebers betydning for marginaliserede unge indvandrere. Københavns Universitet, Psykologisk Laboratorium: Speciale afhandling.

Højholt, C. (1993): Brugerperspektiver. Foraldres, laceres og psykologers erfaringer med psykosocialt arbejde. København: Dansk psykologisk Forlag.

Højholt, C. (1999): Udvikling og deltagelse. Ph.D.-afhandling ved Københavns Universitet.

Jensen, Mørch \& Nissen, m.fl. (1993): På eget ansvar. En evaluering af Ama'r Totalteater. Rubikon. 
Kousholt, D. \& Bostrup, M. (1998): Jeg tror også meget, at det er noget samfundsmaessigt. Københavns Universitet, Psykologisk Laboratorium: Speciale afhandling.

Kvale, S. (1996): InterViews. An introduction to Qualitative Research Interviewing. Sage Publications.

Lather, P. (1999): Postmodernism, Post structuralism and Post(Critical) Ethnography: Of Ruins, Aporias and Angels. Draft as part of a ph.D. course at Gender and women's studies, University of Copenhagen.

Lather, P. (1995): The validity of angels: Interpretive and textual strategies in researching the lives of women with HIV/AIDS. Qualitative Inquiry, 1, 41-68.

Lave, J (in prep.): The Politics of Learning and the Everyday Life. Chapter 8 from the book Changing Practice, under preparation.

Lave, J. \& Kvale, S. (1995): What is anthropological research? An interview with Jean Lave by Steinar Kvale. Qualitative Studies in Education, 8, 219- 228.

Lave, J. \& Wenger, E. (1991): Situated Learning. Legitimate Peripheral Participation. New York: Cambridge University Press.

Lave, J (1996): Teaching, as Learning, in Practice. In Mind, Culture, and Activity. Volume 3, No. 3, 1996.

Lave, J. (1997): Learning, Apprenticeship, Social Practice. In Journal of Nordic Educational Research, Vol. 3. 1997. Special Issue: Apprenticeship - Learning as social practice.

Lihme, B. (1998): Når de unge følger én. Interview med social pædagog \& person Søren Magnussen. Social Kritik 57-58/98.

Malmborg, E. \& Nielsen, J: G. (1999): Projekt De Vilde Unge - en evalueringsrapport. Udviklings- og formidlingscenter for Socialt Arbejde med Unge \& Københavns kommune.

Mørck, L. L. (1995): Praksisforskning som metode, teori og praksis. Udkast nr.1, 1995, 23 årg.

Mørck, L. L. (1996): Livsorienteringer og livsportratter. - Analyser med henblik på at finde muligheder, hvormed marginaliseringsprocesser kan brydes. [Life Orientations and Life Portraits; analysis to find ways to exceed marginality]. Københavns Universitet, Psykologisk Laboratorium: Speciale afhandling.
Mørck, L. L. (1998a): Fremtidens ungdomsskole. Udviklingscenteret for folkeoplysning og voksenundervisning.

Mørck, L. L. (1998b): Den ungdom, den ungdom. Dansk Padagogisk Tidsskift 3/98, p. 3541.

Mørck, L. L. (1998c): Kvalitetssikringens dilemmaer. I Kvalitet Udbytte Kompetence - dialog om voksnes laring. Udviklingscenteret for folkeoplysning og voksenundervisning, 1998, p. 18-21.

Mørck, L. L. (2000): Community based Action Research. Annual Review of critical psychology, Action Research, no.2, july 2000.

Nielsen, K. \& Kvale S. (1999a): Mesterlare. Laring som social praksis. Hans Reitzels Forlag.

Nielsen, K. \& Kvale, S. (1999b): Laring indenfor vekseluddannelsens praktikdel, Undervisningsministeriet.

Nielsen, K. (1999): Musical apprenticeship: Learning at the Academy of Music as Socially Situated. Vol. 24, No. 2. Psykologisk skriftserie. Aarhus Universitet.

Nissen, M. \&Clausen, L (1997): Rammer der rykker. Dafolo.

Nissen, M. (2000a): Practice Research - critical psychology in and through Practices. Annual Review of critical psychology, Action Research, no.2, july 2000.

Nissen, M. (2000b): Projekt Gadebørn. Et fors $\phi g$ med dialogisk, bevagelig og lokalkulturel socialpadagogik med de mest udsatte unge. Frederikshavn: Dafolo.

Nissen, M. (1999): “Wild Learning' - The Beginning of Practice Research about a Project Combining Social work, Staff Training, and Institutional Reform", Working papers. Network for Non- scholastic Learning, No. 9/1999.

Nissen, M. (1998): Brugerindflydelse og handlesammenhænge i psykosocialt arbejde. Skriftserie. Center for Health, Humanity and Culture, No. 1, 1998.

Nissen, M. (1997): Conditions for User Influence in a Social Development Project. Nordiske Udkast 25: 1, 45-64.

Nissen, M. (1996): Undervisning som handlesammenhæng. En kritisk socialpsykologisk analyse. I Højholt, C. \& Witt, G (ed): Skolelivets socialpsykologi. Unge pædagoger. 
Osterkamp, U. (1991): Intersubjektivität und partinahme: Probleme subjektwissenschaftlischer Forschung. I Gekeler/Wetzel (Hrsg.) Subjektivität und Politik. Marburg: Verlag Arbeit und Gesellschaft GmbH. p. 143-187.

Rasmussen, O. V. (1994): Brugerperspektiver og organisationsudvikling. Udkast nr. 1, s. 87- 114.

Stringer, E. T (1999): Action Research. Second Edition. Sage.

Østergaard, L. (1999): Behandling på den selvejende institution Kongens $\varnothing$. Århus Universitet: Center for Rusmiddelforskning.

Østerlund, C. (1996): Learning across Contexts: A field Study of Salespeople's Learning at Work. Skriftserie for Psykologisk Institut. Vol. 21 (1), Aarhus Univercity.

Varenne H. \& McDermott, R. (1998): Succesful Failure. The School America Builds. West view Press.

Wackerhausen, S. (1997): The scholastic Paradigm and Apprenticeship. I Nielsen, K. \& Kvale S. (ed): Journal of Nordic Educational Research: "Apprenticeship: Learning as Social practice.

Wenger, E. (1998): Communities of practice. Learning, Meaning, and Identity. Cambridge University Press. 